\title{
Teaching and Learning Portuguese as a Second Language for Deaf Students: Reflections on Teaching Practices in An Inclusive Context
}

\author{
Michelle Nave Valadão \\ Department of Languages, Federal University of Viçosa (UFV) \\ Carlos Antonio Jacinto \\ Department of Languages, Federal University of Viçosa (UFV)
}

\begin{abstract}
In Brazil, according to the principles of bilingualism, the process of teaching written Portuguese to deaf people should be based on methodologies used to teach a second language (L2). Also, the teaching method should be developed from experiences with the Brazilian Sign Language (LIBRAS). On that account, the present study investigated the teaching-learning process of the written Portuguese experienced by a deaf student in an inclusive class. A qualitative, descriptive and exploratory research was conducted. As for collecting data, three methods were explored: participant observation, field diary and document analysis. The results indicated that in the aforementioned process, LIBRAS was not appreciated as a first language (L1). They also showed that no Portuguese language teaching methodology based on a L2 was used. Thus, we concluded that the methods used for teaching the written language in the inclusive situation did not meet the principals of bilingual education and did not embody all the linguistic and cultural singularities of the deaf student.
\end{abstract}

Keywords: Teaching and learning Portuguese, Brazilian Sign Language (LIBRAS); Deafness.

\section{Introduction}

It's widely known that the process of teaching and learning a written language must begin and be developed throughout the first stages of school life, since, according to Hagen, Miranda \& Mota (2010), the success of this undertaking "influences all the later stages of schooling"* (p. 136). According to the authors, on these first years, reading and understanding the written language constitutes a landmark for the children's autonomy, which, in turn, become "capable of reading important information and better understand the world around them" (p. 136) and, "thanks to these abilities, are able to learn new things throughout their academic lives" (p. 136)

Teaching Portuguese in its written form to Brazilian deaf students has been an ongoing concern to researchers and teachers, since, historically, these students perform poorly when writing and reading is concerned, and usually don't have the opportunity to use the language in a social context. The situation is very problematic, once we consider that ordinary teaching methodologies, based on oral and auditory strategies can't be employed due to the students' lack of sense of hearing, therefore requiring the methodology employed in teaching L2. Furthermore, teaching process must be based on the deaf students' previous knowledge, and on their experiences with the Signs Language (SL). According to Pereira (2012), it's through Libras that the "deaf students may dote with sense what they read, instead of being mere decoders of the written language, and so they can build their knowledge of Portuguese through comparisons of said language with the Sign Language" (p.238)

However, future Portuguese Language $(\mathrm{PL})$ teachers aren't taught in college methodologies for teaching the language to deaf students. It should be mentioned that, in Brazil, the discipline of Libras is compulsory for all undergraduate courses, as established by Decree No. 5,626 / 2005 (Brazil, 2005). However, despite its importance, only one discipline covering the subject isn't enough to provide the necessary training for teachers and also does not contemplate the continued formation of teachers who graduated before the enactment of the mentioned decree, and already worked with deaf students. As a consequence, the Portuguese Language teaching currently offered to the deaf is not adequate for teaching $L 2$, nor does it consider the students' cultural singularities 
In the field of Applied Linguistics, researches about the teaching of PL as $L 2$ are incipient. Recent researches point towards the need of inquiries that take into account the particularities of these students, their linguistic differences and the use of methodologies and strategies adapted to their ages and social background. In relation to the teaching of PL as non-native language in Brazil, according to Gomes (2014) "discussions about the method and methodology, in the same premise of teaching a foreign language, are nowhere to be found" (p.30). Still according to the author "teachers are trained to teach $\mathrm{PL}$ as a mother tongue, not as a foreign language" (page 30), or as L2 or additional language.

Based on these evidences, we developed a research whose objective was, after observing classes attended by a deaf student in an inclusive school, to engage in a discussion about language teaching in the educational context. In this article, we describe the teaching practices we observed, aiming at promoting a discussion regarding the problems of PL teaching experienced at school. We will also reflect upon the teachers' own training, focusing on methodological issues that value and consider deaf students' linguistic, cultural and social diversities.

\section{Contextualizing the linguistic condition of deaf Brazilians in the educational context}

In Brazil, a legal consensus regarding the linguistic condition of deaf people has only been reached as recently as two decades ago, as a result of intense mobilization of the deaf community's part in a struggle for their linguistic rights, resulting in the approval of Law $n^{0}$ 10.436, of April 24, 2002 (Brazil, 2002), which recognized "the Brazilian Language of Signs Libras and the expressions and resources employed by it as an official language ". In this context, the PL assumed a position of $\mathrm{L} 2$, since said law, in its single paragraph, states that "the Brazilian Language of Signs (Libras) can't replace the written form of the Portuguese Language" (Brazil, 2002).

Following the promulgation of the law, discussions on the linguistic conditions of the deaf in Brazil were not limited to the legitimation of Libras as an official language of the country; they went further ahead and recognized, according to Teske (2012), the deaf as multicultural bilingual ${ }^{1}$ citizens. In addition, as discussed by Valadão and Gomes (2016), they also covered questions about the roles that Libras and PL should play in the different social and educational contexts experienced by the deaf. Based on these discussions, the December 22, 2005 Decree 5.626 (Brazil, 2005) regulated the mentioned law and established specific processes for its implementation, highlighting the inclusion of Libras as a compulsory curricular discipline in teacher training courses; the training of Libras' teachers and instructors; the use and dissemination of Libras and PL with the goal of widening deaf people's access to education; the training of Libras/PL interpreters and the guarantee of the right to education of the deaf or hearing impaired.

That period was also marked by changes in the sphere of special education, with the Brazilian government choosing to adopt an inclusive educational system, supported by the World Declaration of Education for All (Brazil, 1990) and the Declaration of Salamanca (Brazil, 1994), effectively enrolling students with disabilities, including deaf students, in ordinary schools.

Ever since, Brazilian educational policies regarding deaf students became part of this new inclusive panorama supported by the legislation previously mentioned, without, however, considering more appropriate approaches or even a meaningful discussion suiting those new policies. Few strategies were devised, such as Libras becoming compulsory for undergraduate courses. However, according to Valadão and Gomes (2016), teachers who were already involved in basic education, before such initiative was put to practice, were also caught up in these policies and, therefore, welcomed deaf in their classes without having the necessary training. According to the authors, this situation generated a linguistic conflict, since teachers and students were not prepared to live with the SL in the school space, in a bilingual situation. As for the PL, inclusive schools also failed to offer a teaching that considered it as L2, since teachers did not have didactic and methodological training to deal with the linguistic and cultural singularities of the deaf, considering their different approaches on how to interact and interpret the world, through visual experiences, as defended Valadão, Mendonça, Silva \& Carmo (2016).

Concerns about the process of training those teachers were also raised by Lebedeff (2006) and Mélo, Araújo \& Soares (2012) when interviewing said professionals. In their reports, educators described themselves dissatisfied with their performances in classrooms, and aware that they lacked specific training for dealing with deaf students. The testimonies also revealed lack of knowledge about deaf students' different needs, as well as a lack of fluency in Libras itself. In addition, they mentioned difficulties in working together with the Libras/PL interpreter, as well as developing teaching methodologies that included both deaf and non-deaf students.

Considering the problems of teacher training for deaf people in inclusive schools, we devised a study whose aim is to investigate the teaching and learning process of $\mathrm{PL}$ as $\mathrm{L} 2$, based on the experiences of a deaf student who attended an 
inclusive class in the year 2016. In order to achieve this objective, we analyze the PL teaching methodologies used by PL teachers, and describe the didactic resources used, as well as the tasks and activities proposed for teaching written Portuguese as L2.

\section{Methodology}

The empirical development of this research was done in a public educational institution of the municipality of Viçosa, Minas Gerais state, Brazil, a school that offers Elementary and Middle School. The target audience was a deaf student, aged 16, enrolled in an inclusive class with 30 other listening students, the two PL teacher teachers, and the Libras/LP translator/interpreter.

The present study was characterized as a descriptive analytical type research. As for the of approach, we chose the qualitative one, since we believe that it provides significant results in the educational area, in the sense of giving the researcher a broader vision of the school daily life, besides producing knowledge and contributing to the transformation of the studied reality. Thus, Lüdke and André (1986), point out that this type of research has the natural environment as its direct source of data and the researcher as its main instrument.

With regard to data collection techniques, field journals, participant observations and documentary analysis were used. The data collected were organized into theoretical and empirical categories, and analyzed based on the findings of other published researches in the field, in order to find similarities, differences and correlations between all them. In these analyzes, we look for patterns and regularities and seek explanations that support or question the hypothesis raised throughout the work. We reflect on the influence of the use (or absence) of Libras and visual methodologies in the teaching and learning process of written LP, as well as on the dynamics involved in this process.

\section{Results and Discussion}

The results presented here correspond to the observations made in the first half of 2016, which covered the months of April to July. It should be mentioned that, during this period, two teachers were assigned to said class. The first teacher (Teacher I) worked in the period between March and May, and ended her activities after being nominated to a position in a public school. The second teacher (Teacher II) took over the class in early June, replacing the first.

\section{Teacher I}

In an initial conversation, the teacher informed us that she had no knowledge of Libras since she had graduated before the inclusion of the language as a compulsory curricular subject in undergraduate teacher courses. She reported that she tried to learn Libras on her own through classes available on the internet, but didn't succeed because she found it extremely difficult to understand and produce signs. The teacher's speech can be interpreted according to the inventory of beliefs described by Gesser (2012), pointing out that among the beliefs about the nature of Libras, the idea that it is difficult language demonstrates "the apprentice's fear of the task of learning" (p. 70). The author argues that learners, by assuming the challenges of studying a new language, establish a correlation with their mother tongue.

The teaching practices of this teacher were usually restricted to recording the contents on the board, while giving explanations, sometimes with her back to the class, while the students wrote down notes. On these occasions, we observed that the deaf student did not follow the explanations, because while copying the contents available on the board, he could not look at the interpreter who signaled the teacher's speech. Faced with the incompatibility between the two visual stimuli, after the student finished copying, the interpreter made a synthesis of the explanations given by the teacher regent, independently and based on what she (the interpreter) had understood, which sometimes didn't coincide with the explanation given previously by the teacher. Situations such as these were also reported by Lima (2012), and, according to that researcher, demonstrate the low expectations of teachers regarding the deaf, even delegating their roles to the interpreters.

The teacher's posture is related to her initial speech of lack of training for working with deaf students before the inclusive proposal. Her practice in the classroom disregarded the linguistic condition of the student, making it impossible for her to access the knowledge through Libras, even if she relied on the mediation of the translator/interpreter. In turn, the interpreter's position revealed an inadequacy as to its role in the school context. According to Felipe (2003), such inadequacy can be attributed to a professional identity that has not yet been consolidated. In this sense, Quadros (2004) also observed several ethical problems during the process of linguistic intermediation in the classroom, where, on many occasions observed by the author, the interpreters took over the role supposed to be the teacher's 
In order to better elucidate the dynamics of the classes and their implications for the process of teaching and learning PL for the deaf student, we will now describe an activity whose objective was to work the narrative genre. In this activity, the teacher began the lesson weaving explanations about the narrative genre. She then asked the students to write a narrative textual production, ranging from 15 to 25 lines, and let them freely choose pick a subject of their interest. The deaf student opted to work on the theme of death and, in order to begin his production, he first developed all his text in Libras along with the interpreter. Only after writing in Libras did he initiate the written text. The practice was adequate to the assumptions of bilingual education, which advocated the use of SL as the basis for the development of PL as L2. Pereira's (2014) research showed that in the teaching and learning process of the PL, the deaf should first develop their texts in SL, because only then can they comprehend what they've read and make sense of what they'll write in L2. As an example, see the textual production (1) of the student transcribed below:

\section{Death}

In death people is happy, because relieves pain, suffering. Many problems in the world today. Example: natural disaster, fish dying due to dirty water, also people dying, losing their homes. We also see violence, bomb, wars. Children losing their parents, many suffering in the family because torn apart, loose their parents become alone, very hard. Today even passing through, but very dangerous in the cities. ${ }^{2}$

From the transcription above, we could perceive that the production elaborated by the deaf student couldn't be described as a narrative text. However, at no time was this informed to him, which, in our opinion, impaired learning and didn't enable the student to acquire this knowledge in PL.

Practically all the activities carried out by the deaf student in the classroom could be reduced to taking notes: writing down the contents off the board, borrowing notes from the classmates and transcribing contents from the book. The student wrote down everything that the teacher put on the board, without understanding or critically analyzing the contents. According to Goes \& Tartuci (2012), a well-observed attitude among deaf students attending regular schools is the habit of taking notes mechanically without any understanding of the content. The authors attribute this behavior to deaf people's necessity of taking part in activities, since the strategy, although contradictory, breaks down "immobility" and keeps them "alive in the environment" (295). In turn, Silva (2000) attributes this behavior to the absence of communication between the deaf student and the listening teacher, which causes the student's participation to be inhibited and the contents not being understood.

As for to the methodologies employed by the teacher, we can see that her work was mainly focused on the grammatical contents of the PL, with a few instances in which she focused in textual elaboration. She also introduced figures of speech, in which she presented the difference between connotative and denotative language, and between literal and figurative sense. Some classes were also devoted to the study of the narrative genre.

With regard to the methodologies employed by the teacher, we can see that her work was mainly focused on the grammatical contents of the PL, with a few instances in which she focused on textual elaboration. She also introduced figures of language, in which she presented the difference between connotative and denotative language, and between literal and figurative sense. Some classes were also devoted to the study of the narrative genre. Her teaching methodology was limited to writing on the board, explaining orally and asking the students to do some exercises related to the topics at hand. Libras was not present in the interactions between the teacher regent and the student. The language was only used when the interpreter signaled what the teacher was communicating to the class. Given this, the disregard of the peculiarities and linguistic specificities of this deaf person became clear, since there was no common linguistic territory with the other class interlocutors. At almost all times, the student only communicated with the interpreter and stopped interacting with the teacher and the other students in class. With the listening peers, a few interactions occurred when they sought to make the deaf student participate in some group activity. At such moments, attempts at dialogues occurred through different communication strategies, such as gesticulation and lip reading. None of the activities were adapted for the deaf student, who appeared to be "invisible" to his classmates. In the more general aspects of classroom conduction, such as elaboration of activities, tests and other methodological procedures, the performance went on in the same vein; both for the deaf student and for the listening students, and the contents were always worked in the same way.

After analyzing these practices, we found that there was no understanding of Libras as the natural language of the student, and that the PL teaching process was not based on L2. These results demonstrate the need to broaden the discussions about PL teaching for deaf students when training teachers, highlighting the language as a social practice that, for such students, should be considered from the point of view of their linguistic and cultural singularities. 


\section{Teacher II}

The second teacher, in an initial conversation with the researchers, informed us before starting work with the class that she also had no knowledge of Libras and that she had not been informed by the school management about the presence of the deaf student in the classroom.

From the start, said teacher showed signs of interest, more so than the first teacher, and she was interested in working with the specifics of the student, always questioning us, and also the interpreter, how she should behave, what to do and what not to do when interacting with the deaf student.

Subsequently, to further address the contents taught by the first teacher, she continued explaining figures of speech, followed by literary genres, this time talking about "chronicles"*. To do so, she took materials prepared and selected by her, which ventured further from the way the subject was addressed by the textbook. Her methodology focused on written texts, an approach she used for both teaching about chronicles and figures of speech.

After some classes on chronicles, the teacher, as an evaluation activity, proposed that group activity for the students, in which they would have to choose a chronicle, read it and prepare a play to be presented to the whole class. However, for the deaf student, she assigned a distinct activity, and asked him to analyze a book called "The Incredible Hulk: Buried in the Mine" and write a summary. It should be mentioned that the book was a comic book and didn't cater to the chronicle genre. In addition, he wasn't asked to participate in the staging along with the other colleagues. The inadequacy in the selection of the activity, differentiating it from that oriented to hearing students, coincided with the observations of Karnopp \& Pereira (2012) when they verified that the pedagogical practices of PL teachers don't consider the language capacity of deaf students. According to the authors, due to the belief that the deaf have many difficulties with reading and writing, it's common for "teachers to assign deaf students adaptations of original works, or works aimed at a younger audience, unsuitable for the students' interests or age"(page 131). The activity occurred without any concern regarding the lack of interaction between the deaf student and the others, which contradicted with the inclusive proposal, since according to Carvalho and Barbosa (2008), for the inclusion process to happen, the ideal is a collaborative environment in which both deaf and hearing students can take part in school activities. Also regarding adapted activities, Gonçalves \& Festa (2013) affirm that the presence of the deaf student in the classroom requires, on the part of the teacher, the elaboration of new teaching strategies that are appropriate to the particularities of the student's learning strategies, in order to transform the classroom into an inclusive space. Hence, it's necessary to teach accordingly the visual-spatial perspective, with the use of images, figures, photos, films, for the access to the curricular content to be effective.

In light of the above, in relation to the teaching methods used by the second teacher, we noticed the focus on textual analysis, how to elaborate and identify a specific genre, the chronicle. Her teaching methodology focused on writing on the board, oral explanations and the use of materials and activities developed by her. On a few occasions, the textbook was used. We also verified that one of the few adapted activities, the play in which the student didn't take part, besides depriving the student of the opportunity of being part of an inclusive work - a situation in which Libras could have been used - the teacher also limited his learning, since the mentioned comic book not only didn't have any relation with the subject matter as it was also beneath the student's presumed capabilities at that point of his school life.

After analyzing the collected data, we observed that, although the teacher demonstrated awareness about the need of a different approach, in practice, her attempts weren't successful, and, similarly to the first teacher, she wasn't capable of recognizing Libras as the student's $L 1$, therefore, the teaching of PL was not based on $L 2$ methodologies. These results demonstrated the importance of broadening the discussions about PL teaching for deaf students in teacher education and about the role that Libras should play in an inclusive school environment, considering a school that includes a bilingual curriculum.

\section{Final Considerations}

When analyzing the PL teaching and learning process experienced by a deaf student from an inclusive public school in the municipality of Viçosa, MG, we focused our interests on the didactic and methodological procedures used by PL teachers, as well as on the relationships among teachers, the interpreter and the deaf student.

Our observations pointed out a misunderstanding on the part of these teachers about Libras being the natural language of the deaf student, a fundamental language for learning PL and other subjects. In those moments when we were in the classroom, the few communications established between the teachers and the deaf student were only possible through the mediation of the interpreter and were limited to the transmission of information, not encompassing exchange of knowledge 
and communicating ideas. Nor did we witness the use of methodologies for the teaching of PL as $L 2$, which would meet the specificities of the student. Furthermore, we noticed a great difficulty in the implementation of didactic and methodological strategies adapted to the deaf, and an inadequacy in the planning of practices that took into account the presence of the interpreter as mediator of communication between the deaf and the hearing in classroom environment.

Although our findings may bring doubts about the teachers' work, we emphasize that at no point do we consider them responsible for solving any problems regarding difficulties in the teaching and learning process of $P L$ as $L 2$ by the deaf, since this process involves discussions in the field of public policies, linguistics, and educational contexts that weren't addressed in this research. In addition, throughout the time we were present at the school, we noticed that the teachers were also dissatisfied with their actions and aware of their lack of training for dealing with the deaf in accordance to the inclusive proposal parameters.

In addition to the issues related to the teachers' performance, we also observed that the student's learning was also impaired due to the inadequate conduct of the translator/ interpreter of Libras/PL. In most of the classes observed, we found that the translator/ interpreter performed functions that were not compatible with her professional assignments, such as promoting explanations about PL content. We also verified that this behavior impaired the student's autonomy, because the professional's interference didn't allow him to reflect on his doubts, nor to independently perform the activities proposed by the teacher, even those that didn't depend on Libras translation/interpretation, such as writing a narrative by himself.

Finally, we found that Libras was present only in the student's relations with the interpreter. We know that the presence of this professional in the classroom is fundamental to mediate the communicative relations between the deaf and the hearing, minimizing the communicative obstacles. However, the interpreter doesn't solve the problem of education for the deaf, because the educational environment is still thought of and organized by and for listeners. In order for this environment to be adapted to the specifics of deaf students, besides the use of Libras by teachers and hearing student, changes in curricular and methodological adaptations are also necessary, albeit unfortunately still far from happening anytime soon, as discussed by Lacerda (2006).

In view of the above, we can conclude that in that school, Libras didn't play a prominent role in teaching practices directed at deaf students, and PL was not approached as L2, nor included in a bilingual curriculum. These results demonstrate the need to broaden the discussions about the teaching of $\mathrm{PL}$ for the deaf as a social practice, based on their linguistic and cultural singularities. We know that in Brazil the theme is incipient and, therefore, we hope that our research can contribute to expand and strengthen similar studies focused on the teaching of PL for the deaf and, specifically, training teachers to better tackle this issue.

\section{References}

[1] Brasil. (1990). Declaração Mundial sobre Educação para Todos: plano de ação para satisfazer as necessidades básicas de aprendizagem. Brasilia.

[2] (1994). Declaração de Salamanca e linha de ação sobre necessidades educativas especiais. Brasília: UNESCO.

[3] Diário Oficial da União (2002). Lei no 10.436 de 24 de abril de 2002, que dispões sobre a Língua Brasileira de Sinais - LIBRAS e dá outras providências.

[4] Diário Oficial da União (2005). Decreto $n^{0} 5.626$ de 22 de dezembro de 2005, que regulamenta a Lei no 10.436, de 24 de abril de 2002, que dispõe sobre a Língua Brasileira de Sinais - Libras, e o Art. 18 da Lei no 10.098, de 19 de dezembro de 2000.

[5] Carvalho, E. de C., \& Barbosa, I. (2008). Pensamento Pedagógico e as NEE: introdução à deficiência auditiva.

[6] Felipe, T. A. (2003). A função do intérprete na escolarização do surdo. Congresso Internacional do INES, Rio de Janeiro, 2, 87-98.

[7] Gesser, A. (2012). O ouvinte e a surdez: sobre ensinar e aprender a Libras. São Paulo: Parábola Editorial.

[8] Góes, M. C. R., \& Tartuci, D. (2012) Alunos surdos e experiências de letramento. In Lodi, A.C.B., Mélo, A. D. B., \& Fernandes, E. Letramento, bilinguismo e educação de surdos (pp. 289-302). Porto Alegre: Mediação.

[9] Gomes, Anderson S. (2014). Metodologias de ensino/aprendizagem de Língua Portuguesa como L2 para surdos. Curitiba: Universidade Tecnológica Federal do Paraná, Faculdade de Letras.

[10] Gonçalves, H. B., \& Festa, P. S. V. (2013). Metodologia do professor no ensino de alunos surdos. Ensaios Pedagógicos, 6, 1-13. 
[11] Hagen, V., Miranda, L. C., \& Mota, M. M. P. E. (2010). Consciência morfológica: um panorama da produção científica em línguas alfabéticas. Psicologia: Teoria e Prática, 12(3), 135-148.

[12] Karnopp, L. B., \& Pereira, M. C. C. (2012). Concepções de leitura e escrita na educação de surdos. In Lodi, A.C.B., Mélo, A. D. B., \& Fernandes, E. Letramento, bilinguismo e educação de surdos (pp. 125-134). Porto Alegre: Mediação.

[13] Lacerda, C. B. F. L. (2006). A inclusão escolar de alunos surdos: o que dizem alunos, professores e intérpretes sobre essa experiência. Cadernos Cedes, 26(69), 163-168. dx.doi.org/10.1590/S0101-32622006000200004

[14] Lebedeff, T. B. (2006) O que lembram os surdos de sua escola: discussão das marcas criadas pelo processo de escolarização. In Thoma, A. S., \& LOPES, M. C. A invenção da surdez II: espaços e tempos de aprendizagem na educação de surdos (pp. 47-62). Santa Cruz do Sul: Edunisc,.

[15] Lima, N. M. F. de. (2012). Inclusão escolar: o dito e o feito. In Lodi, A.C.B., Mélo, A. D. B., \& Fernandes, E. Letramento, bilinguismo e educação de surdos (pp. 303-332). Porto Alegre: Mediação.

[16] Lüdke, M., \& Andre, M. E. D. A. (1986). Pesquisa em educação: abordagens qualitativas. São Paulo: EPU.

[17] Mélo, A. D. B., Araújo, J. R., \& Soares, F. P. (2012).O direito dos surdos à educação (um estudo com jovens de 14 a 22 anos). In Lodi, A.C.B., Mélo, A. D. B., \& Fernandes, E. Letramento, bilinguismo e educação de surdos (pp. 333-371). Porto Alegre: Mediação.

[18] Pereira, M. C. C. (2012). Papel da língua de sinais na aquisição da escrita por estudantes surdos. In Lodi, A.C.B., Mélo, A. D. B., \& Fernandes, E. Letramento, bilinguismo e educação de surdos (pp. 235-246). Porto Alegre: Mediação.

[19] (2014). 0 ensino de português como segunda língua para surdos: princípios teóricos metodológicos. Educar em Revista. 30(2), 143-157. http://dx.doi.org/10.1590/0104-4060.37236

[20] Quadros, R. M. (2004). O tradutor e intérprete de língua brasileira de sinais e língua portuguesa. Secretaria de Educação Especial - Programa Nacional de Apoio à Educação de Surdos. Brasília: MEC; SEESP.

[21] Valadão, M. N., Mendonça, A. C. V., Silva, F. S., Carmo, A. J. (2016). Ensino-aprendizagem e metodologias de ensino de Língua Portuguesa para surdos na perspectiva da educação inclusiva. Revista Língua \& Letras, 35(17), 163-186.

[22] Valadão, M. N.; Gomes, E. G. Percepção de professores em formação inicial sobre o ensino da Língua Brasileira de Sinais. Todas as Letras, 18(1), 199-211. http://dx.doi.org/10.15529/1980-6914/letras.v18n1p199-211

[23] Silva, A. B. P. (2000). O aluno surdo na escola regular: imagem e ação do professor. Unpublished Master's degree dissertation, Universidade Estadual de Campinas, Campinas, Brazil.

[24] Teske, O. (2012). Surdos: um debate sobre letramento e minorias. In Lodi, A.C.B., Mélo, A. D. B., \& Fernandes, E. Letramento, bilinguismo e educação de surdos (pp. 25-47). Porto Alegre: Mediação.

\section{Footnotes}

1 Para os surdos, a condição bilíngue tem como pressuposto a aquisição da língua de sinais como língua materna/primeira língua, por ser considerada natural aos surdos, visto que se apresenta de modalidade espaço-visual, não dependendo, portanto, da audição para ser adquirida; e a língua oficial do país como segunda língua (Quadros, 1997). For the deaf, the bilingual condition is based on the fact that they acquire the Signs Language as their, other tongue/first language, as it is considered more natural to them, once it encompasses visual-spatial comprehension, being independent, thus, from any hearing capabilities, and the official language of their country as a second language

${ }^{2}$ Portuguese Language activity, writing a narrative. Source: Research data. 